\title{
Uniwersytet w świetle ustawy o szkolnictwie wyższym i nauce z 3 lipca 2018 r. Wybrane zagadnienia
}

\section{Streszczenie}

Ustawa o szkolnictwie wyższym i nauce z 2018 r. w poważnym stopniu ogranicza autonomię wewnętrzną $\mathrm{w}$ uczelni. Zarządzanie oddaje $\mathrm{w}$ ręce rektora i rady uczelni a pomija wydziały, które, o ile w ogóle będą powołane, zostały sprowadzone do roli podmiotów bez istotnego znaczenia. Rektor jako wyłączny kierowniczy organ uczelni i rada uczelni, reprezentująca przede wszystkim interesariuszy zewnętrznych, jako organ nadzoru nad jej gospodarką, uzyskali tak szerokie kompetencje, że w konsekwencji może to wpływać negatywnie na rozwój wielu dyscyplin naukowych, zwłaszcza z dziedziny nauk humanistycznych oraz w wielu przypadkach także społecznych.

Słowa kluczowe: modele uniwersytetu, autonomia uniwersytetu, organy uniwersytetu, struktura uniwersytetu, rada uczelni, statut uniwersytetu, wydział

1 Prof. dr hab. Anna Łabno - kierownik Katedry Prawa Konstytucyjnego Wydziału Prawa i Administracji Uniwersytetu Śląskiego; e-mail: anna.labno@us.edu.pl; ORCID: 0000-0002-2669-2733. 


\title{
University in the Light of the Act on Higher Education and Science of 3 July 2018. Selected Issues
}

\begin{abstract}
The Act on Higher Education and Science of 2018 considerably restricts the internal autonomy of universities. Management is vested in rectors and university boards while neglecting the role of fac-ulties, which, if established in the first place, have been reduced to entities of no significance. The rector, as the exclusive managerial body of an institution, and the university board, representing mainly external stakeholders, as a body supervising its economy, have been vested with such an ex-tensive authority that this may result in hindering the development of multiple academic disciplines, especially those in the area of the humanities, but also in the field of social studies in many cases.
\end{abstract}

Keywords: university models, university autonomy, university governing bodies, university struc-ture, university board, university statutes, faculty 


\section{Wstęp}

Na propozycję napisania opinii w sprawie nowej ustawy o szkolnictwie wyższym i nauce zareagowałam pozytywnie, uznając, że warto wziąć udział w debacie na ten temat, chociaż procedura legislacyjna jest już na końcowym etapie ${ }^{2}$. Oznacza to praktycznie brak wpływu na stanowisko władz publicznych, jednak być może głos ten zostanie wzięty pod uwagę w przyszłości. Kiedy zapoznałam się dokładnie ze stroną internetową Ministerstwa Nauki i Szkolnictwa Wyższego naszły mnie kolejne poważne wątpliwości. Po co pisać, skoro wszystkie organizacje akademickie reprezentujące władze uczelni wyższych, w tym również uczelni zawodowych, przedstawiły swoje stanowisko pozytywne, a nawet pochwalne. Żaden z oficjalnych podmiotów, którego powołanie wymuszają i gwarantują przepisy prawa, mam na myśli także władze uczelni zorganizowane w różne konferencje i inne struktury o podobnym charakterze, nie dostrzega problemów, które przecież, chociażby statystycznie, muszą wystąpić. Przeczytać można tylko listy pochwalne, czyżby nikt nie widział żadnych zagrożeń, a ustawa wprowadzała naukowy raj? Trudno nie postawić pytania, czy nie nadsyłano do Ministerstwa także głosów krytycznych? Czy nie należało przedstawić polemiki? Nie było jej? Podobny zarzut można by postawić także mnie, nie pojechałam na Kongres Nauki, nie pisałam do Ministerstwa, więc dlaczego dziś stawiam tyle pytań i mam tak zasadnicze wątpliwości. Podpisałam jeden z protestów, dołączając się w ten sposób do aktywnie wyrażanych postulatów wprowadzenia zasadniczych zmian w projekcie.

W tym krótkim opracowaniu nie sposób poddać analizie wszystkich ważnych kwestii. Jednak nie tylko dlatego, że brak na to czasu, ale również z tego powodu, że w wielu przypadkach konieczna byłaby specjalistyczna analiza, do której brak mi wystarczającego przygotowania. Nie roszczę sobie pretensji do wyczerpania argumentacji, ani też nie twierdzę, że istnieją tylko takie argumenty, jakie przedstawiam. Nie twierdzę także, że istnieje tylko „moja koncepcja”. Niemniej z perspektywy doświadczenia zawodowego pracownika naukowo-dydaktycznego oraz pełnionych funkcji prodziekana i prorektora uważam, że mam wystarczające kompetencje, aby o wielu sprawach uniwersytetu dyskutować.

2 Tekst pisałam na przełomie czerwca i lipca, a więc $\mathrm{w}$ trakcie postępowania ustawodawczego, dlatego korzystałam z tekstu ustawy z dnia 3 lipca 2018 r. Prawo o szkolnictwie wyższym i nauce, tekst przekazany do Senatu. 


\section{O organach uniwersytetu i jego strukturze}

Uniwersytet to instytucja badawcza, kształcąca i w obu tych rodzajach swojej aktywności współdziałająca z otoczeniem; wzajemne oddziaływanie jest koniecznym elementem permanentnego kształtowania się uniwersytetu, jego rozwoju i możliwości badawczych oraz kształcenia w konkretnych zawodach. Uniwersytet jest także ośrodkiem kształtującym kulturę ogólną i postawy obywatelskie.

Dla mnie to truizm, także jako podstawa „ideowa” współczesnego uniwersytetu. Opowiadam się za takim właśnie uniwersytetem. Jest on koniecznym podmiotem każdej społeczności, umożliwiając jej istnienie i rozwój. Moim zdaniem taki uniwersytet powinien działać również we współczesnej Polsce, ponieważ jest niezbędny dla utrzymania i rozwoju kultury, w tym kultury narodowej i regionalnej. Uniwersytet traktowany jako instytucja kulturotwórcza i kształcąca w wielu niematerialnych dziedzinach nie stoi w sprzeczności z koncepcją uczelni prowadzącej badania i edukację w zakresie takich nauk, które są decydujące dla rozwoju gospodarki państwa, w tym jej innowacyjności. Warto jednocześnie zauważyć, że rozwój gospodarczy potrzebuje odpowiedniego otoczenia kulturowego i nie byłoby rozwiązaniem korzystnym, gdyby pomniejszać rolę uniwersytetu w tej dziedzinie.

Powstaje pytanie, jak analizowana ustawa reguluje funkcje uniwersytetu i czy może zapewnić takie jego działania, jakie wskazałam wyżej? Twórcy ustawy nie ułatwiają znalezienia odpowiedzi, uzasadnienie do ustawy w ogóle nie zawiera wskazówek ukierunkowujących czytelnika tak, aby mógł zapoznać się z preferowanym przez projektodawcę modelem uniwersytetu. Uzasadnienie stanowi jedynie opis przyjętych regulacji. Sposób unormowania działania uniwersytetu przyjęty w ustawie również jednoznacznie nie przesądza o jego modelu, co jest o tyle korzystne, że daje szanse kształtowania go w praktyce stosowania ustawy. Mam nadzieję, że w kierunku wskazanym wyżej, aczkolwiek możliwości te są bardzo niewielkie ${ }^{3}$.

Zdaję sobie jednak sprawę, że dla wielu współczesnych mi naukowców przedstawiona wyżej koncepcja uniwersytetu wyrosła z założeń tzw. uniwersytetu Humboldta, nie musi wcale oznaczać rozwiązania adekwatnego do współczesnych potrzeb i oczekiwań. Jednak czy pozostawienie takich jego cech jak autonomia, struktura wydziałowa, udział społeczności akademickiej w zarządzaniu uczelnią muszą być uznane za anachroniczne, niepozostające w żadnym związku z potrzebami współ-

3 Trzeba jednak zaznaczyć, że projekt ustawy złożony w Sejmie w większym stopniu aniżeli ostateczne uregulowanie był ukierunkowany na powiązanie uniwersytetu z jego otoczeniem gospodarczym. Ta zmiana nie oznacza jednakże, aby można było uznać, że koncepcja reformy uległa istotnej zmianie. 
czesnego świata? Albo takimi się wydawać, gdy je postrzegać z perspektywy nałożonego ustawą obowiązku podejmowania działań na rzecz innowacyjności gospodarki (art. 1 ustawy)? Krótko mówiąc i w pewnym uproszczeniu, chodzi o to, czy współcześnie uniwersytet może realizować funkcje, które nie przekładają się bezpośrednio na efekt gospodarczy? A ponadto, czy może wykonywać funkcje wymagające wsparcia materialnego ze strony państwa, a efekty tej aktywności będą polegały na kształtowaniu szeroko rozumianej kultury niematerialnej? Istotne jest także, kto w uniwersytecie powinien decydować o kierunku jego działalności? Jakie organy uniwersytetu i w jakim stopniu zewnętrzni interesariusze powinni mieć wpływ na działalność badawczą i edukacyjną uniwersytetu?

W istocie chodzi o wybór koncepcji uniwersytetu, która byłaby odpowiednia dla celów stawianych nauce w Polsce, a więc poczynając od koncepcji Humboldta, przez uniwersytet przedsiębiorczy, po tzw. uniwersytet odpowiedzialny społecznie. Podstawą pierwszego z wymienionych jest wolność działalności badawczej prowadzonej przez wybitnych uczonych oraz inne wolności akademickie, a także jedność badań naukowych i kształcenia ${ }^{4}$. W drugim modelu podkreśla się samodzielność uniwersytetu, elastyczność struktury, z której wyeliminowano wydziały, a wprowadzono centra badawcze i edukacyjne ${ }^{5}$. Ta forma organizacji musi być jednak oparta na konsensusie wspólnoty akademickiej. Powoływane organy kolegialne, których potrzeby istnienia się nie neguje, mają tylko funkcje doradcze. Ponadto źródła finansowania są zdywersyfikowane i oprócz państwowego możliwe są prywatne. Uniwersytet przedsiębiorczy to uniwersytet oparty na wiedzy, którą jest zdolny wykorzystywać na rzecz interesariuszy zewnętrznych, czyli najkrócej rzecz ujmując, realizować potrzeby rynku. Taki uniwersytet jest więc ekonomicznie opłacalną instytucją, gdyż jest zdolny realizować samodzielnie swoje potrzeby finansowe i zakres wsparcia państwowego jest ograniczony.

Natomiast najistotniejszą cechą uniwersytetu odpowiedzialnego społecznie jest, z punktu widzenia prowadzonych wywodów, kwestia zdolności uczelni i jej otoczenia do wzajemnego zrozumienia swoich potrzeb i współdziałania ${ }^{6}$. Uniwersytet to już nie tylko instytucja prowadząca działalność badawczą na rzecz otoczenia zewnętrznego, ale także korzystająca z możliwości podejmowania działalności w zakresie wszelkich nauk, a więc nie tylko tych, które umożliwiają praktyczne zastosowanie. Etos nauki czystej i stosowanej ma takie samo znaczenie. W takim uniwersytecie zwiększa się wpływ ciał kolegialnych, a więc wspólnoty akademickiej na kierunek zarządzania, a pozycja rektora ulega ograniczeniu. Istotne znaczenie

\footnotetext{
$4 \quad$ K. Leja, Zarządzanie uczelnią. Koncepcje i wspótczesne wyzwania, wyd. 2, Warszawa 2013, s. 72.

5 Ibidem.

6 Ibidem, s. 202-203.
} 
dla aktywności uniwersytetu mają nie tylko interesariusze zewnętrzni, ale również wspólnota akademicka.

Nie wnikając w szczegółowe rozwiązania, mogę uznać, że jest to wizja współczesnego uniwersytetu, która odpowiada mojemu wyobrażeniu o jego roli jako ośrodka badawczego i edukacyjnego. Jednocześnie działającego w oparciu o zasadę autonomii, która jest niezbędna dla prawidłowej działalności badawczej i edukacyjnej. Uniwersytet przedsiębiorczy nie spełnia takiej roli ani jako centrum badawcze, ani też edukacyjne. Podstawową tego przyczyną jest związanie interesami zewnętrznymi, które bardzo często może powodować uzależnienie w wyborze kierunków badawczych od celów przyjętych przez interesariuszy. Zagrożenie tego rodzaju jest realne zwłaszcza w przypadku niskiego finansowania uniwersytetu ze środków publicznych. W takim przypadku będą dominować nauki stosowane. Inne zaś skazane zostaną na ograniczone możliwości rozwoju, co w konsekwencji może doprowadzić do ich zaniku.

Podsumowując, powstaje pytanie, jaki uniwersytet kreuje ustawa i jakie mogą być tego konsekwencje? Wymaga to analizy jej szczegółowych postanowień. Uzasadnienie dołączone do ustawy nie wskazuje celów, które ustawodawca zamierza zrealizować, ani też nie przybliża nas do konkretnych ustaleń. Podobnie kilka przepisów w początkowej części aktu czyni to ogólnikowo i raczej propagandowo. Nie ma zatem możliwości jednoznacznego rozstrzygnięcia tej kwestii. W uzasadnieniu można się natomiast zapoznać $\mathrm{z}$ bardzo szczegółowo przedstawioną negatywną oceną stanu polskiej nauki i edukacji.

Pytania dotyczące rodzaju i charakteru funkcji przypisywanych uniwersytetowi w ustawie i wynikających stąd konsekwencji, mają swoje źródło w uregulowaniu w zupełnie inny sposób niż dotychczas wielu różnych kwestii decydujących o funkcjonowaniu uniwersytetu. Przede wszystkim dotyczy to organów uniwersytetu i struktury organizacyjnej uczelni. Mają one bowiem decydujące znaczenie dla kierunku reformy i następnie zarządzania uczelnią.

Ustawa likwiduje dotychczasową strukturę jednostek podstawowych uniwersytetu, a więc wydziały, nie powołując w to miejsce innych. Natomiast statut uczelni może przewidywać utworzenie jednostki podstawowej, którą może być wydział. Jeśli chodzi o organy uczelni, to zgodnie z ustawą mają być obligatoryjnie powołane trzy. Są to rektor i senat oraz zupełnie nowy organ, rada uczelni. Przyjęte regulacje oznaczają, że ustawa niemal całkowicie zrywa z tradycyjną strukturą uniwersytetów.

Zasadnicze znaczenie dla koncepcji polskiego uniwersytetu ma powołanie nowego organu, rady uczelni, która ma być reprezentantem interesariuszy zewnętrznych wobec niej. Szczególne uprawnienia ustawa przewiduje dla rektora, którego pozycję zwieńcza uznanie domniemania jego kompetencji. Natomiast pozycja senatu została mocno ograniczona. 
Rada uczelni to organ liczący od 6 do 8 członków oraz przewodniczącego samorządu studenckiego. Jest szczególnie ważne, że co najmniej 50\% składu (po wyłączeniu przewodniczącego samorządu), stanowić mają osoby spoza wspólnoty uczelni. W ten sposób ustawa tworzy organ o bardzo specyficznym składzie. Będzie to miało istotny wpływ na podejmowane przez nią decyzje, gdyż jak należy założyć, przynajmniej połowie członków tego organu specyfika uniwersytetu jest obca. Dodatkowo, jeśli przyjąć, że skład konkretnej rady spełnia tylko minimum organizacyjne ustawowo określone, to trudno nie postawić co najmniej dwóch pytań. Po pierwsze, jakie będą skutki decyzji podejmowanych przez radę, gdy w jej składzie przewagę będą mieli członkowie nienależący do wspólnoty uczelni. I po drugie, jaka będzie rola przewodniczącego samorządu i konsekwencje, jakie to może mieć dla działania i rozwoju uniwersytetu ${ }^{7}$. Istnienie takiego organu stanowi poważne zagrożenie dla działalności uniwersytetu rozumianego jako instytucja, która realizuje funkcje znacznie szerzej określone, aniżeli poszukiwanie nowych, ekonomicznie opłacalnych programów badawczych i edukacyjnych, a więc może swobodnie prowadzić badania podstawowe i ma realną możliwość szerokiego oddziaływania kulturowego. Jest to tym bardziej realne, że rada uczelni została wyposażona w bardzo poważne kompetencje. Ma decydujące znaczenie w procedurze powoływania rektora, gdyż zgłasza jego kandydaturę, którą senat jedynie opiniuje, a wyboru dokonuje kolegium elektorów oraz, skrótowo rzecz ujmując, kontroluje jej gospodarkę. Należy uznać, że takie uregulowanie kompetencji rady stanowiącej w swej istocie organ obcy uczelni, jest formą tworzenia w Polsce modelu uniwersytetu przedsiębiorczego, czyli działającego na rzecz interesariuszy zewnętrznych. Takie ukierunkowanie reformy uniwersytetu będzie miało fundamentalne znaczenie dla polskiej humanistyki i nauk społecznych. Jeśli kryterium sensu jego istnienia i oceny poziomu staje się przede wszystkim troska o realizację celów gospodarczych, to wskazane wyżej grupy nauk uniwersyteckich stają się mało znaczące, wręcz opóźniające rozwój Polski. To technokratyczne postrzeganie uniwersytetu spowoduje negatywne konsekwencje także dla rozwoju nauk ścisłych i technicznych, gdyż żadna dyscyplina naukowa nie może istnieć i rozwijać się w próżni kulturowej. Jeśli do tego uregulowania, o którym pisałam wyżej dołączyć technokratyczne podejście do oceny dorobku naukowego pracowników naukowych i piśmiennictwa naukowego, to w ciągu najbliższych kilku lat nastąpi głęboki kryzys polskich uniwersytetów,

7 Warto zauważyć, że w tekście projektu złożonym do laski marszałkowskiej skład rady był inny, gdyż ustawa wymagała więcej niż połowę członków pochodzących spoza uczelni. Oznaczałoby to możliwość przegłosowania wniosków w radzie większością członków spoza uczelni i faktycznie pełną zależność uniwersytetu od osób spoza uczelni. W znacznym stopniu powodowałoby to ograniczenie jej autonomii, lub w skrajnych przy padkach konkretnych decyzji nawet całkowite. 
a ich rzeczywista odbudowa będzie wymagała dziesięcioleci ${ }^{8}$. Myślę, że dobrym punktem odniesienia dla dostrzeżenia znaczenia tej kwestii, jest efektywność nauki w szkole podstawowej i średniej. Warto też zastanowić się nad kwestią mierzalności kryteriów oceny pracy naukowej w humanistyce i naukach społecznych a w naukach stosowanych.

Funkcje powierzone radzie uczelni powodują, że organ ten przypomina do pewnego stopnia radę nadzorczą spółki. Uniwersytet nie jest spółką i nie trzeba wyjaśniać, że nie powinien być zarządzany jak spółka. I to niezależnie od tego, jakiego rodzaju uniwersytety istnieją dziś w Polsce, czy jakie powołamy. W moim przekonaniu uniwersytet zawsze powinien być postrzegany jako instytucja naukowa, nie zaś działająca jak quasi-przedsiębiorstwo, jednak zawsze mająca na celu użyteczność społeczną swojej aktywności. Użyteczność społeczna uniwersytetu (podkreślam uniwersytetu, a nie uczelni innego typu) ma niewiele wspólnego z działalnością gospodarczą i efektywnością mierzoną wynikami w tej dziedzinie. Natomiast istnieją kryteria, które nie mieszcząc się w tej kategorii, służą jednak określeniu użyteczności społecznej i dotyczą przede wszystkim rozwoju humanistyki i kultury szeroko pojętej, a także nauk społecznych.

Nie oznacza to jednocześnie, by uczelnia nie była zobowiązana do racjonalnej działalności, w tym racjonalnego gospodarowania swoimi funduszami. Nie ma też żadnych przeszkód, a nawet byłoby wskazane, aby w dziedzinach, które ze swej istoty umożliwiają współpracę z podmiotami gospodarczymi, takowa była prowadzona. Sądzę natomiast, że powołanie rady i przyznanie jej kompetencji o tak dużym znaczeniu, jak przyjęte $\mathrm{w}$ ustawie nie jest odpowiednią metodą.

Wzmocnienie pozycji rektora było w ostatnich latach bardzo stanowczo postulowane i być może jest to trafne dążenie. Jednak nasuwają się wątpliwości, jaki ma to przybrać kształt? Zgodnie z ustawą rektor w szczególności reprezentuje uczelnię i nią zarządza, przedstawia projekt statutu oraz projekt strategii uczelni, które są uchwalane przez senat, powołuje osoby pełniące funkcje kierownicze w uczelni oraz je odwołuje. Te kilka uprawnień pokazuje, jak wielki jest zakres i merytoryczne znaczenie funkcji rektora. Niewątpliwie, wraz z radą uczelni, która, co należy w tym miejscu podkreślić, jest wyłącznym podmiotem uprawnionym zgłaszać kandydatury w wyborach rektora, dysponują niemal nieograniczoną władzą.

Ustawa przyjęła zatem model centralistyczny kierowania uniwersytetem, ale nie zostały wskazane mocne argumenty, które by to uzasadniały. Daremne są ich poszukiwania w uzasadnieniu do projektu ustawy. Można natomiast odwołać się

8 Wątku tego nie będę rozwijała w tym opracowaniu, gdyż zagadnienie to jest zbyt obszerne, jak na przyjętą objętość tekstu. Niemniej należy stanowczo podkreślić, że ma ono podstawowe znaczenie dla pracy naukowej. 
do różnych opracowań teoretycznych dotyczących kształtowania się idei uniwersytetu. Jeżeli głębiej poszukać źródeł rozumowania polskiego projektodawcy, można założyć, że odwołuje się do koncepcji struktury elastycznej. Elastyczna struktura miałaby stanowić jeden z niezbędnych elementów nowego typu uczelni, a mianowicie uniwersytetu przedsiębiorczego opartego na wiedzy, który wykorzystuje paradygmat organizacji opartej na wiedzy ${ }^{9}$.

Analiza ustawy potwierdza zastosowanie pewnych elementów charakterystycznych dla takiej koncepcji. Wymienić należy jednoosobowe zarządzanie rektora, oraz elastyczną strukturę wewnętrzną, która jest ustawowo nieokreślona i przynajmniej teoretycznie pozostawiona do ustalenia w statucie. Nie wydaje mi sięjednak realne, by w uniwersytecie, którego raczej w warunkach polskich należy zaliczyć do uczelni dużych, byłoby możliwe ograniczenie struktury do wskazanej w ustawie.

Regulacja struktury nastąpi więc w statucie, co ma bardzo duże znaczenie formalne. Statut jest aktem prawa wewnętrznego całkowicie podporządkowanym ustawie. W konsekwencji pozycja organów uczelni powoływanych na mocy statutu jest niska, zwłaszcza w stosunku do organów ustawowych. Przede wszystkim może mieć to istotne znaczenie praktyczne w stosunkach z rektorem i radą uczelni. Trzeba też mieć na uwadze, że na rzecz rektora przewidziane jest domniemanie kompetencji.

Zgodnie z upoważnieniem, jakie daje ustawa do uregulowania w statucie, rektor powoła z pewnością swoich zastępców, jednak nie wpłynie to na ograniczenie jego pozycji, gdyż w każdym przypadku będą oni działali z jego upoważnienia. W tym zakresie system zarządzania uczelnią będzie funkcjonował bardzo podobnie do aktualnego.

Rektor może także powołać, jak to już w początkowym okresie prac nad ustawą proponowano, na przykład pełnomocników zastępujących dzisiejszych dziekanów, albo po prostu dziekanów. Sądzę, że będzie musiał to uczynić, bowiem nie ma praktycznie innej możliwości, aby zarządzać uczelnią. Czyli będą pełnomocnicy rektora, a być może warto pomyśleć o zastępcach owych pełnomocników, bo podobnie jak aktualnie działają dziekan i prodziekani, tak po wejściu w życie ustawy nie zmieni się zakres pracy jego formalnego następcy i samodzielnie nie będzie mógł tym obowiązkom sprostać. I pewnie też nie będzie chciał, tym bardziej mając tak niski status.

Podsumowując, uczelnia to nie przedsiębiorstwo rządzące się kalkulacją ekonomiczną a w dodatku rektorzy rzadko są przygotowani do biznesowego zarządzania. Rektor jest specjalistą w swojej dziedzinie i dlatego nie jest przygotowany do oceny specyfiki pracy badawczej w innych, zwłaszcza jeśli należą one do zupełnie odmiennych, jak nauki ścisłe i humanistyczne wraz ze społecznymi. Dlatego decen-

$9 \quad$ K. Leja, op. cit., s. 158. 
tralizacja uprawnień na rzecz dziekanów kierujących wyodrębnionymi jednostkami organizacyjnymi wyposażonych w pewien zakres uprawnień władczych pozwalała na gruncie starej ustawy na zachowanie i racjonalne wykorzystanie potencjału naukowego. Istotne znaczenie miały $w$ tej dziedzinie także rady wydziału.

W omawianej ustawie pozycja rektora wzrasta, ale to oznacza jednocześnie, że wzrasta także jego odpowiedzialność. Nie tylko wynikająca z przepisów prawa, ale również wyrażająca się w opinii pracowników uczelni oraz studentów. Przede wszystkim jednak chodzi mi o oceny pracowników, których wizje roli uniwersytetu i działalności badawczej są wynikiem nie tylko tego, co nazywamy interesami, ale także są podyktowane odmiennością dyscyplin naukowych, które uprawiają. Na te trudności i w konsekwencji zakres rzeczywistej odpowiedzialności nałożą się ponadto problemy wynikające z realnego finansowania i działalności rady uczelni, która wymuszać będzie ukierunkowanie zarówno badań naukowych, jak i kierunków kształcenia w zgodzie z interesami rynku, który będzie reprezentować.

Na zakończenie analizy poświęconej organom uniwersytetu i jego strukturze organizacyjnej należy przyjrzeć się pozycji senatu. Organ ten będący reprezentantem różnych grup społeczności akademickiej między innymi uchwala statut oraz strategię uczelni oraz powołuje i odwołuje członków rady uczelni oraz opiniuje kandydatów na rektora. Warto przypomnieć, że kandydaturę rektora zgłasza rada uczelni, projekt statutu i strategii uczelni przedstawia rektor, a opiniuje rada uczelni. Senat jest ponadto uprawniony dokonywać oceny działania uczelni oraz formułować rekomendacje dla rady uczelni i rektora w zakresie wykonywanych przez nich zadań. Uprawnienia senatu mogą mieć istotniejsze znaczenie w zakresie, w jakim dotyczą statutu oraz strategii uczelni, a więc w przypadkach, gdy ma on, przynajmniej formalnie, uprawnienia władcze.

Należy sądzić, że przy takim układzie kompetencji, jaki został w ustawie przyjęty, rada, rektor i senat będą musieli współpracować. W przeciwnym wypadku pojawia się zagrożenie konfliktem. Rektor uzyskuje dominującą pozycję, dopiero gdy statut zostanie uchwalony, a strategia przyjęta.

Ustawa nie przewiduje powołania wydziałów, ale także nie wyklucza. Likwiduje więc klasyczne jednostki organizacyjne oraz ich organy, którymi były dotąd dziekan oraz organ doradczy, rada wydziału. To właśnie wydział i jego organy decydowały o specyfice struktury uniwersytetu, umożliwiając zachowanie i racjonalne współdziałanie różnych wspólnot oraz wykorzystanie ich potencjału naukowego. Aktualnie przyjęta regulacja oznacza pełną centralizację, gdyż choć ustawa stanowi o możliwości powoływania różnych organów, to ustawowy zakres uprawnień organów powołanych w niej expressis verbis, wyznacza zakres kompetencji organów statutowych. Drugorzędna pozycja wydziału została także jednoznacznie uznana poprzez przekazanie senatowi uniwersytetu dotychczasowej kompetencji rady 
wydziału do nadawania stopni naukowych. Nie chodzi bynajmniej o przeciążenie senatu, ale o merytoryczny sens takiego rozwiązania. Fikcyjność decyzji podejmowanej przez senat jest przerażająca. Trudno w ogóle wyobrazić sobie dyskusję na temat przebiegu obrony doktorskiej, czy ocenę postępowania habilitacyjnego w sytuacji, gdy w senacie brak jest specjalistów z danej dziedziny! Czy taka regulacja może przyczynić się do podniesienia poziomu prac naukowych, o czym tak wiele można przeczytać w uzasadnieniu do ustawy! Obrona odbędzie się przed komisją składającą się ze specjalistów, ale o nadaniu stopnia naukowego decydować będzie senat, w którym ich już nie będzie.

W jakim świetle stawia to komisje wydziałowe i w ogóle wszystkich pracowników naukowych? Bardzo często posiedzenia rad wydziału, na których głosowano nadanie stopnia naukowego, były poprzedzone dyskusją na temat wartości naukowej pracy, zasad recenzowania, przebiegu obrony itd. Regulacja przyjęta w ustawie spowoduje pogłębienie negatywnych zjawisk w polskiej nauce.

Analizując regulacje ustawy dotyczące struktury uczelni i kompetencji jej jednostek i organów, zastanawiałam się nad przyczyną rezygnacji ministerstwa z dotychczasowych rozwiązań. Odrzuciłam myśl, że chodzi o ułatwienie tworzenia zespołów badawczych, ponieważ nie dostrzegam w istnieniu wydziałów i katedr dostatecznych podstaw do takiego rozumowania. Moje osobiste doświadczenia oraz obserwacje czynione przede wszystkim w ostatnich dziesięciu latach wskazują, że niezależnie od wieku i pozycji zawodowej można skutecznie ubiegać się o finansowanie badań naukowych i tworzyć zespoły badawcze. W żadnym z tych przypadków nie jest potrzebne zaangażowanie i formalne działanie kierownika katedry. W uzasadnieniu projektu ustawy nie znalazłam żadnego wyjaśnienia. Natomiast przeczytałam, że wskazanie w ustawie organów uczelni i ograniczenie ich liczby spowoduje wzmocnienie ich pozycji. Jest jednak charakterystyczne, że są to organy uczelni szczebla centralnego. Ustawa nie przewiduje żadnego innego organu, aczkolwiek dopuszcza jego powołanie w statucie uczelni.

Od wielu miesięcy twierdzi się powszechnie, że jakaś grupa specjalistów przygotowuje wzorcowy statut uniwersytetu. Nie wiadomo, czyja jest to inicjatywa. Czy to ministerstwo zamierza wspomóc niedojrzałe w swej samorządności polskie uczelnie, czy też jakaś grupa uniwersytetów podjęła taką inicjatywę? Jeśli byłaby to faktycznie inicjatywa ministerstwa, to moim zdaniem mieściłaby się w polskiej praktyce pisania wzorcowych statutów. Towarzyszą one bowiem kolejnym pokoleniom Polaków. Z okresu moich studiów, a także lat kolejnych, pamiętam wzorcowe statuty gmin tworzone po reformie administracji z 1975 r. Wtedy można to było zrozumieć, gdyż jednoznacznie mieściło się w istocie ówczesnego systemu, ale dzisiejsze pojmowanie samorządności powinno być jednak zupełnie inne. Tymczasem także po 1989 r. wspiera się instytucje samorządowe, w tym przede wszystkim samorząd 
terytorialny, wzorcowymi statutami. Być może w tym przypadku pewna jednolitość jest wskazana. Jeśli jednak statut wzorcowy piszą przedstawiciele kilku uniwersytetów to przede wszystkim działanie to jest świetnym przykładem utajnionej pracy zespołowej. Do środowisk uniwersyteckich nie przedostały się, jak dotąd, żadne szczegółowe informacje na temat tych prac. Podobnie zresztą, jeśli to ministerstwo jest $w$ tej materii aktywne. Niezależnie jednak od tego, kto jest zaangażowany w tworzenie tego statutu i na jakich zasadach działa, zastrzeżenia budzi dziwna aura, jaka się wokół tej sprawy wytworzyła. Zupełnie niepotrzebnie.

\section{O jedności działalności badawczej i edukacyjnej}

Zasada przedstawiona w tytule tej części opracowania ma podstawowe znaczenie dla zachowania tradycji uniwersyteckiej. W moim przekonaniu jest decydująca dla specyfiki uniwersytetu, który będąc ośrodkiem badawczym jest jednocześnie ośrodkiem kształcenia. Kariera akademicka to własna praca badawcza i kształcenie. Natomiast ustawa oparta została na zupełnie innym założeniu. Swoistym „ukoronowaniem" tej nowej koncepcji uniwersytetu polskiego ma być profesura dydaktyczna ${ }^{10}$. Warto jeszcze wspomnieć o „Dydaktycznej Inicjatywie Doskonałości” i na koniec można już tylko zapytać, co to dziś znaczy uniwersytet? Studenta kształci profesor dydaktyczny, który nie publikuje, nie wyjeżdża na konferencje?! To może wróćmy do pomysłu na przykład szkół prawa zamiast wydziałów prawa? "Profesorom uczonym" pozostanie dużo czasu na własną pracę badawczą, student będzie się kształcił dzięki profesorom dydaktycznym, którymi zapewne zostaną osoby, które z różnych powodów nie zdążą osiągnąć określonych progów kariery naukowej i tak, upraszczając i obniżając koszty edukacji na uniwersytecie, z pewnością zbudujemy nową jakość. Tym bardziej jeśli posłużymy się „Dydaktyczną Inicjatywą Jakości". To powinno ostatecznie pozwolić nam stworzyć od nowa uniwersytet. Będzie to uniwersytet idealny, który znajdzie się w pierwszej setce listy szanghajskiej. Na koniec tych moich wątpliwości zapytam, trochę przewrotnie, kto za ten luksus podwójnej kadry zapłaci? Dydaktyka będzie tańsza, ale całość?

Jest jeszcze jedna istotna sprawa, a mianowicie jakie są przyczyny rezygnacji z postulatu, by student miał kontakt z profesorem, co jeszcze tak niedawno było istotnym warunkiem jakości kształcenia. Warunek ten, nieraz trudny do spełnienia, stanowił jednak o rzeczywistej wartości uczelni. W każdym razie patrząc na to z perspektywy uniwersytetu, który powinien spełniać nie tylko funkcję ośrodka

10 W toku postępowania ustawodawczego regulacja ta została usunięta. Jednak trzeba o pomyśle tym napisać, aby zdać sobie sprawę, jakie rozwiązania mogą być proponowane. 
badawczego. Powinien także kształcić na najwyższym poziomie i właśnie ten status naukowy stanowi o szczególnym charakterze studiów na uniwersytecie. Stanowi też o różnicy pomiędzy uniwersytetem a innymi szkołami wyższymi. Trudno zrozumieć motywację wprowadzania takich rozwiązań.

A czy u podstaw tego pomysłu nie leży nadmiar kadry na uczelniach i jednoczesny brak studentów? Czy kadra naukowa będzie pracowała tylko na wydziale prawa/w szkole prawa, czy także poza, w wielu miejscach, na co w zmienionych warunkach będzie miała szczególnie dużo czasu? A może właśnie o to chodzi, aby „pozbyć się" czasochłonnych zajęć ze studentami, zwłaszcza w ostatnich latach wyjątkowo uciążliwych z powodu przerostu obowiązków administracyjnych? Prawdą jest, że zwłaszcza nadmiar obowiązków administracyjnych przeszkadza w systematycznej i spokojnej pracy naukowej, ale wiele z tych "pomysłów” można przecież zlikwidować!

I, na zakończenie, może warto byłoby nieco naszych studentów usamodzielnić? Mniej prowadzić za rączkę? Mniej układać wszystko administracyjnie, od wejścia w progi uczelni, po szkołę doktorską. Polska nauka potrzebuje ludzi samodzielnych. Ale to jest kwestia na odrębną zupełnie analizę, moim zdaniem jednak potrzebną, jeśli chcemy polską naukę naprawdę reformować.

\section{Kilka słów podsumowania}

Nowa ustawa w poważnym stopniu ogranicza autonomię wewnętrzną w uczelni, gdyż oddaje zarządzanie w ręce rektora i rady uczelni, a pomija wydziały. W praktyce zostały one sprowadzone do roli podmiotów bez istotnego znaczenia, nawet dotyczy to procedury nadawania stopni naukowych. Rektor jako wyłączny kierowniczy organ uczelni i rada uczelni, reprezentująca przede wszystkim interesariuszy zewnętrznych, jako organ nadzoru nad jej gospodarką uzyskali tak szerokie kompetencje, że w konsekwencji może to wpływać negatywnie na rozwój wielu dyscyplin naukowych, zwłaszcza z dziedziny nauk humanistycznych oraz w wielu przypadkach także społecznych. Istnieje obawa o ukierunkowanie działalności uniwersytetu na nauki stosowane, a w konsekwencji poważne ograniczenie pozostałych, których znaczenie zostanie w ten sposób co najmniej umniejszone. W skrajnym przypadku może to prowadzić do ich zaniku, zwłaszcza w niektórych uniwersytetach. W ten sposób uniwersytet utracić może swoją funkcję animatora w wielu dziedzinach, które mają istotne znaczenie dla społeczeństwa i państwa polskiego. Regulacje ustawy mogą także prowadzić do upadku małych uczelni, które nie będą zdolne dochować wygórowanych wymagań. W konsekwencji prowadzić to może do zachwiania równowagi w rozkładzie możliwości kształcenia w skali kraju. Może 
także ograniczyć skuteczność polityki zrównoważonego rozwoju, a to mogłoby spowodować wiele negatywnych skutków społecznych ${ }^{11}$.

Ograniczenie autonomii to także zagrożenie dla rozwoju nauki w ogóle. Nauka wymaga określonego poziomu wolności i to nie tylko rozumianej ściśle jako wolność nauki. Wymaga także pewnego poziomu zaufania do badaczy. Ta ustawa na pewno nie jest w tym duchu ukształtowana.

Uniwersytet nie może stać się przedsiębiorstwem, które przede wszystkim działa na zamówienie i na rzecz otoczenia zewnętrznego. Funkcje uniwersytetu są znacznie szerzej postrzegane przez bardzo wielu przedstawicieli nauki i polskie społeczeństwo i nie ograniczają się do nauk stosowanych. Tym bardziej, że społeczeństwo potrzebuje nie tylko innowacyjnej gospodarki. Potrzebuje również specjalistów w bardzo wielu dziedzinach, które nie przynoszą bezpośredniego efektu ekonomicznego, są natomiast niezbędne dla dalszego rozwoju Polski.

Jestem przekonana, i nie jest to odkrywcze, że wzgląd na ekonomiczne możliwości państwa ma zasadnicze znaczenie dla kierunku reformy uniwersytetów. Przyjmowane regulacje powinny jednak brać pod uwagę zróżnicowane funkcje różnych dziedzin nauki, ich specyfikę i znaczenie dla rozwoju zarówno nauki jako takiej, jak i całego państwa oraz jego regionów. Chciałabym też podkreślić, że punktem wyjścia powinno być wyraźne i trwałe zróżnicowanie regulacji prawnych dotyczących nauk stosowanych i innych dziedzin nauki uprawianych na uniwersytetach. Nie jest możliwe stosowanie nawet podobnych założeń dla tych całkowicie odmiennych dziedzin.

Na zakończenie chciałabym podkreślić, że reformie polskiej nauki, w tym kształcenia, powinna towarzyszyć odbudowa etosu uczonego i nauczyciela akademickiego.

11 Na aspekt ten zwracano uwagę $\mathrm{w}$ wielu krytycznych opracowaniach na temat reformy nauki. 